Int. J. Morphol.,

35(2):684-690, 2017.

\title{
The Plantar Aponeurosis in Fetuses and Adults: An Aponeurosis or Fascia?
}

\author{
La Aponeurosis Plantar en Fetos y Adultos: ¿Aponeurosis o Fascia?
}

A. Kalicharan; P. Pillay; C.O. Rennie; B.Z. De Gama \& K.S. Satyapal

KAlicharan, A.; PILlay, P.; RENNIE, C.O.; DE GAMA, B. Z. \& SATYAPAL, K. S. The plantar aponeurosis in fetuses and adults: An aponeurosis or fascia? Int. J. Morphol., 35(2):684-690, 2017.

SUMMARY: The plantar aponeurosis (PA), which is a thickened layer of deep fascia located on the plantar surface of the foot, is comprised of three parts. There are differing opinions on its nomenclature since various authors use the terms PA and plantar fascia (PF) interchangeably. In addition, the variable classifications of its parts has led to confusion. In order to assess the nature of the PA, this study documented its morphology. Furthermore, a pilot histological analysis was conducted to examine whether the structure is an aponeurosis or fascia. This study comprised of a morphological analysis of the three parts of the PA by micro- and macro-dissection of 50 fetal and 50 adult cadaveric feet, respectively (total $n=100$ ). Furthermore, a pilot histological analysis was conducted on five fetuses $(\mathrm{n}=10)$ and five adults $(\mathrm{n}=10)$ (total $\mathrm{n}=20)$. In each foot, the histological analysis was conducted on the three parts of the plantar aponeurosis, i.e. the central, lateral, and medial at their calcaneal origin (total $n=60)$. Fetuses: i) Morphology: In $66 \%$ (33/50) of the specimens, the standard anatomical pattern was observed, viz. three parts (i.e. central, lateral, medial) that originated from the medial and lateral processes of the calcaneal tuberosity and inserted onto the metatarsals. In $18 \%(9 / 50)$ of the specimens, a two-part structure was observed. Variable origins of the medial part were noted in $16 \%(8 / 50)$ of the specimens. In order to document these variations, the central part of the PA was divided into three segments (i.e. upper, middle, lower): a) In $63 \%$ (5/8) of the specimens, the medial part arose from the middle segment; b) In $37 \%$ (3/8) of the specimens, the medial part arose from the middle and upper segments. ii) Histological analysis: a) The central part contained longitudinally arranged semi-dense type I collagen fibres with fibroblasts; b) The lateral part displayed semi-dense type I collagen fibres with fibroblasts, hyaluronic acid, corpusculum sensorium fusiforme (Ruffini corpuscle) and corpusculum lamellosum (Pacinian corpuscle); c) The medial part comprised of loose connective tissue with elastic and reticular fibres. Adults: i) Morphology: In $100 \%$ of the specimens, the standard anatomical pattern was observed. ii) Histological Analysis: a) In the central part, longitudinally arranged type I collagen fibres with fibroblasts were visible; b) The lateral part contained longitudinally arranged type I collagen fibres with fibroblasts; c) The medial part comprised of loose connective tissue, type I and type III collagen fibres, elastic and reticular fibres. In the current study, the morphology of the PA in fetuses and adults conformed to the standard anatomical description with variations in the origin of the medial part observed in fetuses. In addition, the fetal specimens displayed a two-part structure of the PA when the medial part was absent. Microscopically, the findings suggest that only the central and lateral parts may be considered as the PA, whilst the medial part may be termed the PF.

KEY WORDS: Aponeurosis; Fascia; Histology; Morphology; Embryology.

\section{INTRODUCTION}

The plantar aponeurosis (PA) is a fascial structure that originated from the calcaneus and traversed the foot to insert onto the base of each metatarsal (Kelikian, 2011). The literature reviewed suggested that the PA in adults comprised of three parts viz. central, lateral, and medial (Kelikian; Abrahams et al., 2013; Standring, 2016) (Table I). However, Hiramoto (1983) described the same structure as two parts, viz. central and lateral, whilst Drake et al. (2015) described it as one part, viz. central with the lateral and medial parts termed the plantar fascia (PF) (Table I).
Kalniev et al. (2013) reported the same three-part structure as the PF, which was corroborated by Stecco et al. (2013), in their histological study. From this, it can be seen that there is variability regarding the nomenclature and the classification of the parts of the PA (Table II). The term PA is prescribed in Terminologia Anatomica (FCAT, 1998) whilst the term PF is not recognized.

According to standard histological textbooks, fascia is composed of loose connective tissue with elastic fibres 
Table I. Summary of the literature reviewed showing the description and number of parts of the PA.

\begin{tabular}{|c|c|c|}
\hline \multicolumn{3}{|c|}{ Author(s) and Description of the PA } \\
\hline $\begin{array}{l}\text { One part } \\
\text { (i.e. central) }\end{array}$ & $\begin{array}{c}\text { Two parts } \\
\text { (i.e. central and lateral) }\end{array}$ & $\begin{array}{c}\text { Three parts } \\
\text { (i.e. central, lateral, medial) }\end{array}$ \\
\hline Chaurasia (2010) & Loth $(1908)$ & Do Carmo et al. (2008) \\
\hline S innatamby (2011) & Loth (1913) & Kelikian and Sarrafian (2011) \\
\hline Snell (2011) & Hiramoto (1983) & Chen et al. (2014) \\
\hline Agur et al. (2013) & - & Hoffman et al. (2014) \\
\hline Moore et al. (2014) & - & Abrahams et al. (2015) \\
\hline Netter (2014) & - & Standring et al. (2016) \\
\hline Pavan et al. (2014) & - & - \\
\hline Drake et al. (2015) & - & - \\
\hline
\end{tabular}

Table II. Summary of the literature reviewed showing variability in the nomenclature.

\begin{tabular}{ll}
\hline \multicolumn{1}{c}{ Three parts (i.e. central, lateral, medial) } \\
PA $/$ PF & Kaya (2010) \\
\hline Wearing et al. $(2006)$ & Sakalauskait and Satkunskien_(2012) \\
Standring et al. $(2009)$ & Stecco et al. (2013) \\
McNally and Shetty (2010) & - \\
Kalniev et al. (2013) & \\
\hline
\end{tabular}

Medicine and Medical Sciences, College of Health Sciences at the University of KwaZulu-Natal, South Africa. Bilateral dissection was conducted on fetuses (13 males, 12 females) with a gestational age range of 16-25 weeks, and adults (15 males, 10 females) with an age range between 54-95 years old. The micro-dissection was conducted with the aid of a Zeiss Stemi DV4 microscope. Methodology by Pandey et al. (2015), using the left fetal foot was used for the determination of the gestational age. The PA was viewed in situ after removing the skin and the superficial layer of fat, whilst keeping the superficial neurovascular structures intact. The origin, course, insertion and anatomical relations of the central, lateral and medial parts were documented. Furthermore, a pilot histological analysis was conducted on five fetuses $(n=10)$ and five adults $(n=10)$ (total $\mathrm{n}=20$ ). In each foot, the histological analysis was conducted on the three parts of the PA, i.e. central, lateral, and medial in fetuses and adults just proximal to its calcaneal origin, thus a total of 60 slides were micro-analyzed.

The hematoxylin and eosin (H\&E) stain was performed to determine the histological composition of the three parts of the PA, as this stain revealed basic microanatomical structures.

\section{RESULTS}

\section{Fetuses}

Morphological Analysis. In 33/50 (66 \%) of the fetal specimens, the standard anatomical pattern was observed, i.e. a three-part structure of the PA (central, lateral, medial) that originated from the calcaneal tuberosity and inserted onto the metatarsals (Fig. 1). However, in 9/50 (18\%) of the fetal specimens, a two-part structure, viz. central and lateral, with an absent medial part was observed. In 42/50 was conducted on 50 fetuses and 50 adults (total $n=100$ ) which were obtained from Clinical Anatomy, School of Laboratory 



Fig. 1. Illustration showing the origin, course, and insertion of the three parts of the fetal PA. Key: C - Central part; L - Lateral part; M - Medial part; 1-5 Digital slip. Ca - Calcaneus

(84\%) of the fetal specimens, the PA covered the plantar surface of the first muscular layer of the foot, which comprised of the abductor hallucis, flexor digitorum brevis, and the abductor digiti minimi muscles (from medial to lateral).
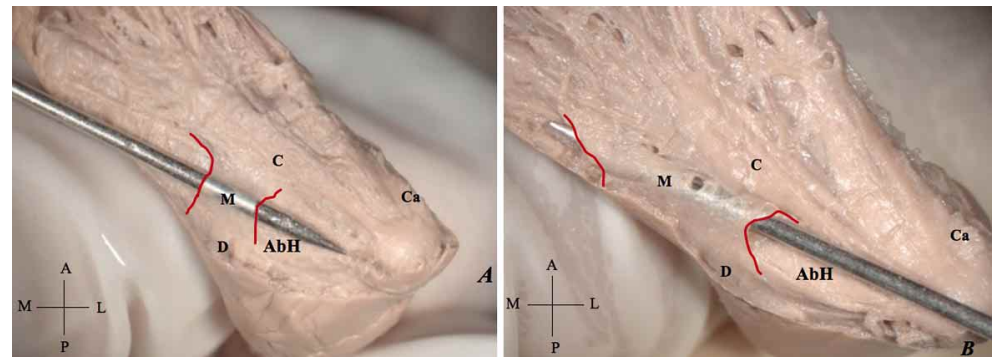

Fig. 2. Variation of the medial part originating from the middle (A) and middle and upper (B) segments of the central part in fetuses. Key: C - Central part; M Medial part; $\mathrm{AbH}$ - Abductor hallucis; D - Dorsal fascia. Ca-Calcaneus
Variations in the medial part of the PA in fetuses. Variations in the origin of the medial part of the PA were observed in 8/50 (16\%) of the fetal specimens. As a result, the origin of the medial part was determined by dividing the central part into three segments, viz. upper, middle, lower. The medial part originated from: a) the middle segment of the central part of the PA and blended with the dorsal fascia on the infero-medial aspect of the foot in 5/8 (63\%) (Fig. 2A); b) the middle and upper segments of the central part of the PA and blended with the dorsal fascia on the infero-medial aspect of the foot in 3/8 (37\%) (Fig. 2B).

\section{Histological Analysis}

The central part of the PA. This contained longitudinal semi-dense type I collagen fibres in a wavy pattern, that were unidirectional in the proximal to distal direction. Scattered fibroblasts and loose connective tissue emerged amongst the collagen fibres (Fig. 3A).

The lateral part of the PA. Semi-dense type I collagen fibres were longitudinally arranged in a wavy pattern, in a proximal to distal direction. Loose connective tissue intertwined between the collagen fibres (Fig. 3B). A significant amount

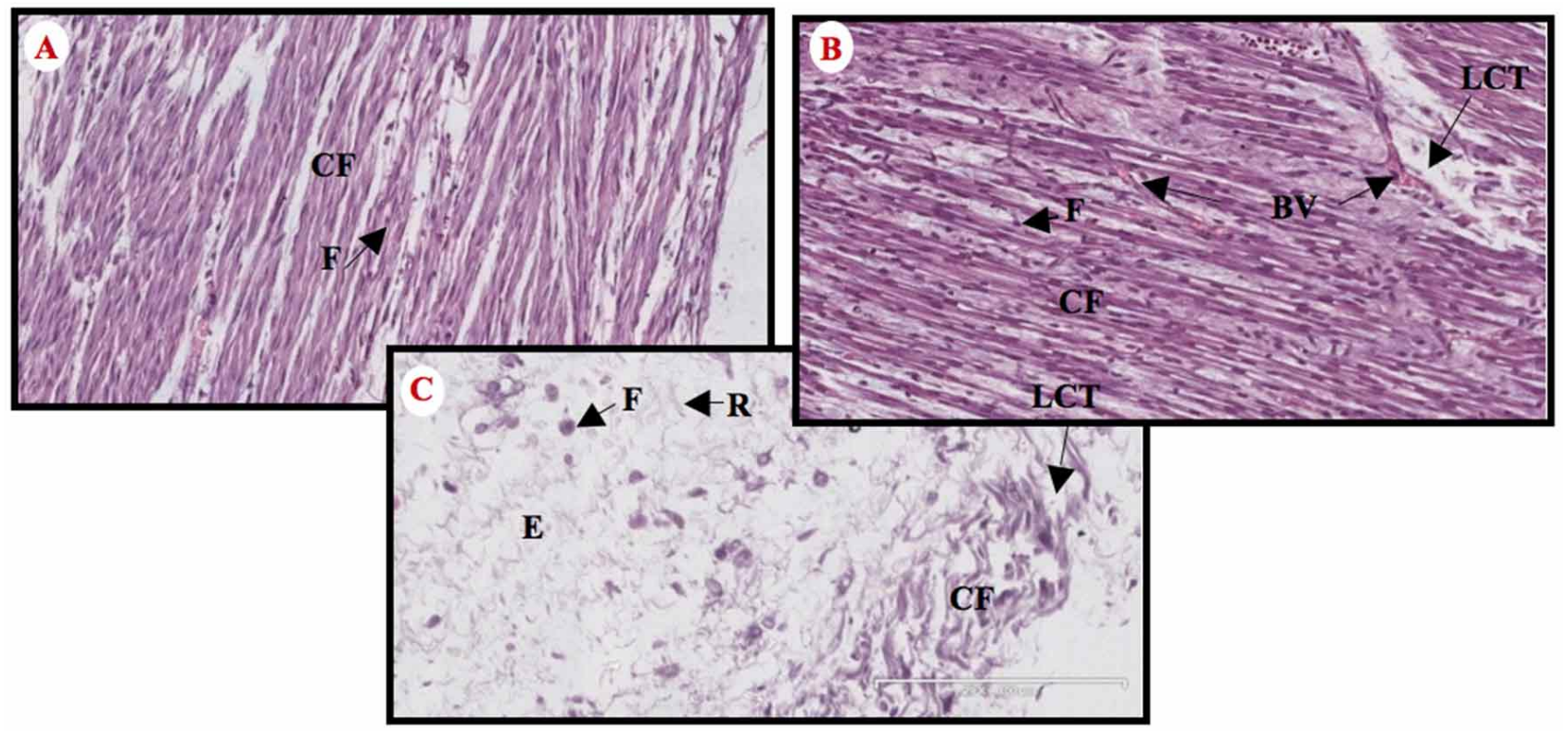

Fig. 3. H\&E stain of the central (A), lateral (B), and medial (C) part of the PA in fetuses near the calcaneal origin. Type I collagen fibres (CF) and scattered fibroblasts (F) arranged unidirectional can be observed in A and B. Loose connective tissue (LCT) were found between the collagen fibres, with blood vessels (BV) in between in B. In C, few loose type I collagen fibres arranged in multiple directions were seen amongst the elastic (E) and reticular fibres (R), which were arranged in an irregular network. 
of fibroblasts, together with hyaluronan and neurovascular structures [(blood vessels, corpusculum sensorium fusiforme (Ruffini corpuscle) and corpusculum lamellosum (Pacinian corpuscle)] were visualized.

The medial part of the PA. This part consisted of loose connective tissue, few wavy type I collagen fibres, with elastic and reticular fibres which presented in a mesh-like arrangement

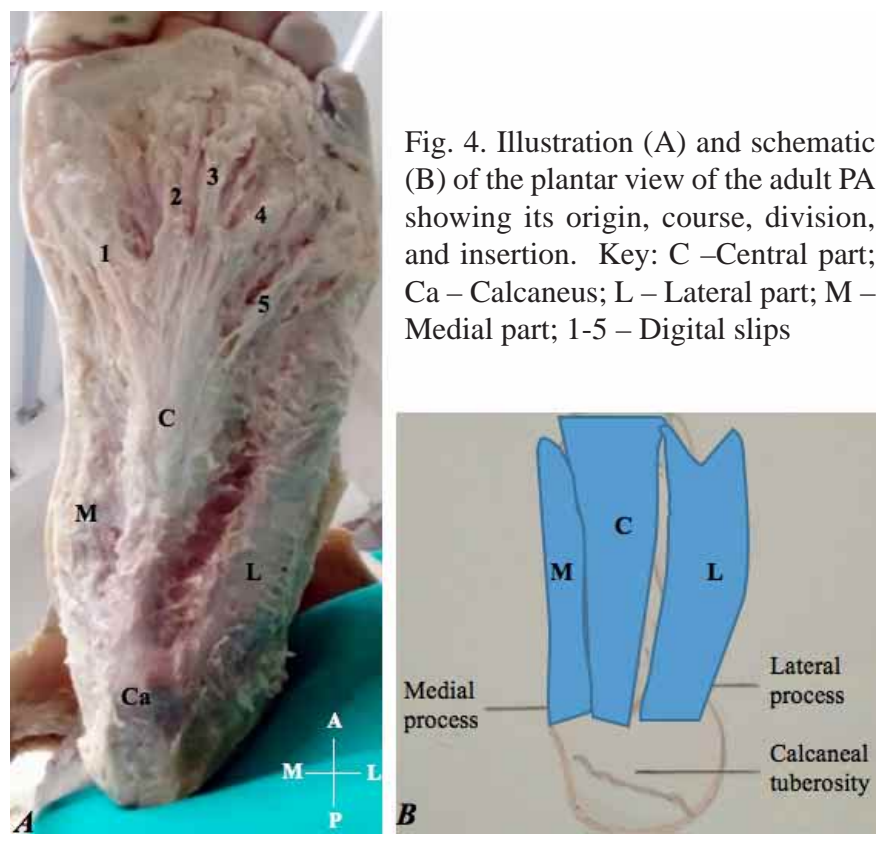

(Fig. 3C). Scattered fibroblasts were also observed. Neurovascular structures and type III collagen fibres were seen in a multi-directional arrangement surrounding the blood vessels.

\section{Adults}

Morphological Analysis. In $100 \%$ of the adult specimens the standard anatomical pattern was observed, viz. three distinct parts: central, lateral, and medial (Fig. 4).

\section{Histological Analysis}

The central part of the PA. This part contained dense straightened unidirectional, longitudinal strands of type I collagen fibres arranged in a proximal to distal direction, with densely compacted fibroblasts (Fig. 5A).

The lateral part of the PA. Densely packed straightened type I collagen fibres in a unidirectional, proximal to distal arrangement, was visualized. At the calcaneal origin,numerous fibroblasts were located (Fig. 5B).

The medial part of the PA. Loose connective tissue intertwined with few type I and type III collagen fibres, and scattered fibroblasts were visible (Fig. 5C). Elastic and reticular fibres were seen in abundance.
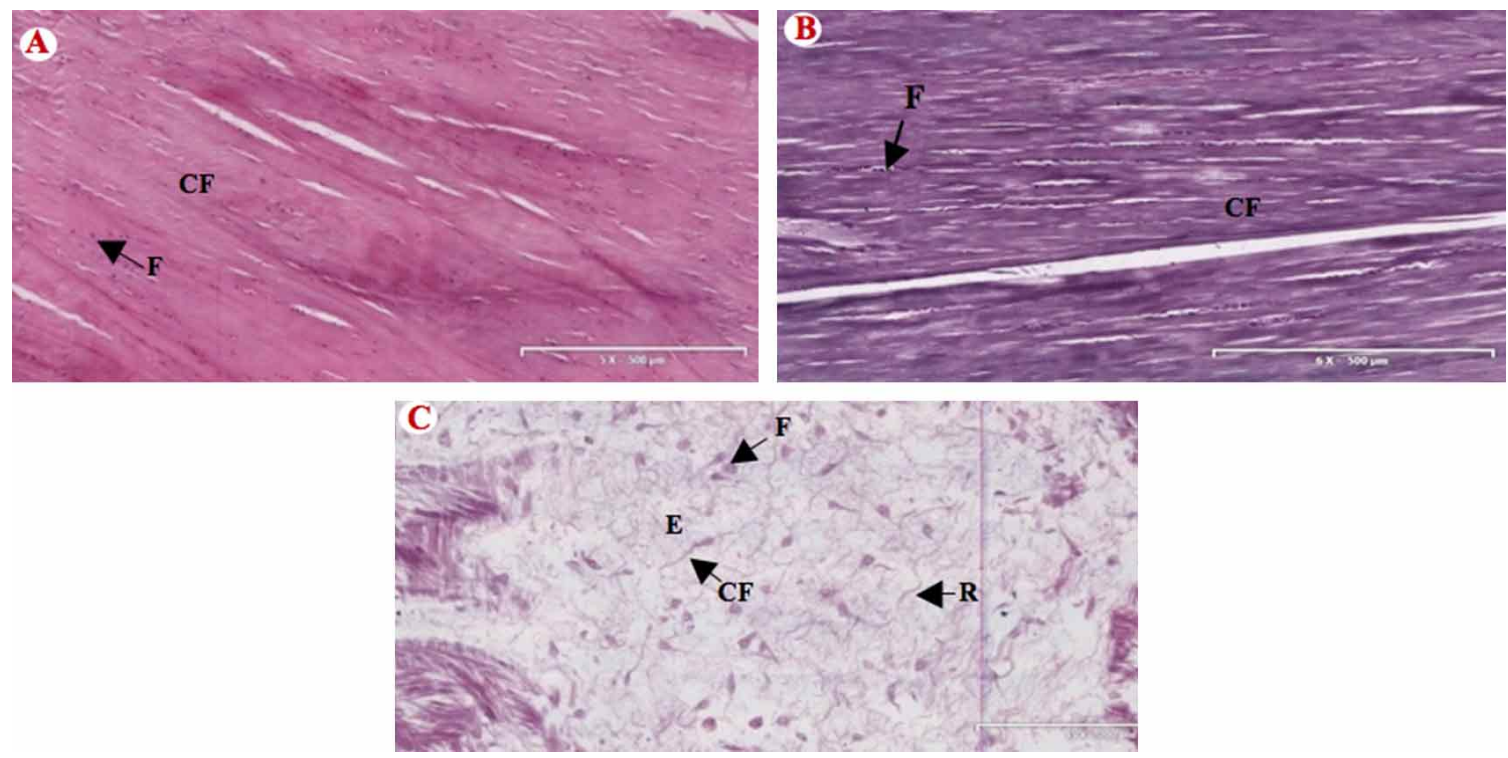

Fig. 5. H\&E stain of the central (A), lateral (B), and medial (C) part of the PA in the adult specimens near the calcaneal origin. Type I collagen fibres (CF) and scattered fibroblasts (F) were seen to be in abundance in A and B. Few loose type I collagen fibres arranged in multiple directions were seen amongst the elastic (E) and reticular fibres (R) in C, which were arranged in an irregular network. 


\section{DISCUSSION}

\section{Fetuses}

Morphology of the PA. The results obtained in this cohort showed the PA comprised of three parts, viz. central, lateral, medial, that originated from the calcaneus $(33 / 50 ; 66 \%)$, except in cases where the medial part was absent $(9 / 50 ; 18$ $\%$ ) suggesting a two-part structure. In 8/50 (16\%) of the sample size, variations in the origin of the medial part were documented. Fetal morphology of the PA and its variations were not previously documented in the literature reviewed. The three-part structure documented in this study for the fetal cohort agreed with the reports of Agur and Dalley (2013), Kelikian and Standring (2016), on the adult literature of the PA. Furthermore, the two-part structure documented in this study agreed with the descriptions by Loth (1908, 1913) and Hiramoto as they also described a two-part structure, viz. central and lateral parts with an absent medial part in an adult cohort with a smaller sample size. The prevalence of two parts of the PA may be of interest to biomechanical engineers and clinicians as it may suggest that the medial part may develop at a later stage or be absent in the adult. These anomalies may also be useful in understanding fetal PA development as the fetal specimens obtained in this study were in the second trimester term of pregnancy.

Histology of the PA. The central and lateral parts comprised of mainly semi-dense type I collagen fibres in a wavy pattern in a proximal to distal unidirectional arrangement. There were no known studies on the histology of the PA in fetuses, therefore, in comparison to the adult studies, the findings of the current study did not agree with the study by Stecco et $a l$., as they reported straightened type I collagen fibres in a multi-directional arrangement. However, neurovascular structures were observed in the lateral parts and this corroborated with the adult study by Stecco et al. The medial parts contained loose connective tissue with few wavy type I and type III collagen fibres in a multi-directional arrangement which corroborated with the adult study by Stecco et al. The central and lateral parts in the fetal cohort fit the description of an aponeurosis and the results obtained for the medial part agree with the description of fascia as per standard histological textbooks (Mescher; Ross \& Pawlina; Moore et al., 2016).

\section{Adults}

Morphology of the PA. The results obtained in this study for the adult cohort showed that the PA comprised of three parts, viz. central, lateral, and medial, that originated from the calcaneus and traversed the foot as reflected in standard anatomical textbooks (Kelikian; Abrahams et al.; Standring, 2016). This was also reported by other authors, however, they used interchangeable terminologies, i.e. PA and PF (Wearing et al., 2006; McNally \& Shetty, 2010; Kalniev et al.) or PF (Kaya, 2010; Sakalauskaite \& Satkunskiene', 2012; Stecco et al.) to describe this structure. More recently (2016), a three-part structure termed the PA was reported by Standring (2016), thus the current study corroborates well with this author. Furthermore, the PA had been documented as a two-part structure (Loth, 1908, 1913; Hiramoto) or a one-part structure (Agur \& Dalley, 2013; Moore et al., 2014; Drake et al.); however, this was not documented in the current study for the adult cohort. Macroscopically, the central and lateral parts of the PA in the adult cohort were observed to be thicker and more opaque than the medial part. Hence, advocating for a review of its micro-anatomy which may prove useful in explaining this differentiation.

Histology of the PA. The central and lateral parts comprised of mainly type I collagen fibres observed in a straight unidirectional pattern. Whereas, the medial parts contained loose connective tissue with very few type I collagen fibres in a multi-directional arrangement, as well as type III collagen fibres that surrounded blood vessels. These findings did not agree with the study by Stecco et al., as they reported straightened type I collagen fibres in all three parts observed in a multi-directional arrangement which they termed the PF (Table III). Furthermore, their study also documented type II collagen fibres seen in the lateral and medial parts, which were not visualized in the current study. This could be due to the different material used, viz. fresh and formalinfixed adult cadaveric material by Stecco et al., whereas, the present study utilized embalmed adult cadaveric material. The results of the adult cohort for the central and lateral parts fit the description of an aponeurosis and the results obtained for the medial parts agreed with the description of fascia as per standard histological textbooks (Mescher; Ross \& Pawlina; Moore et al., 2016).

\section{CONCLUSION}

The interchangeable use of the terms "plantar aponeurosis" and "plantar fascia" by several authors has led to much confusion regarding its structure and composition, from which variable descriptions of the plantar aponeurosis emerged. This study confirmed the anatomy of the adult PA as described in standard anatomical textbooks and previous literature, with the addition of fetal anatomy since it was not reported previously. This may offer insight into the development of the fetal PA between the 6th -25 th week intra-uterine. Histological analysis revealed that only the 
Table III. Comparison of histological composition of the PA.

\begin{tabular}{|c|c|c|c|}
\hline \multirow{3}{*}{ Parts of the PA } & \multicolumn{3}{|c|}{ Authors } \\
\hline & \multirow{2}{*}{$\begin{array}{l}\text { Stecco et al. (2013) } \\
\text { Adults }\end{array}$} & \multicolumn{2}{|c|}{ Kalicharan et al. (2016) } \\
\hline & & Adults & Fetuses \\
\hline \multirow{4}{*}{ Central part } & Type I collagen & Dense type I c ollagen & Semi-dense type I collagen \\
\hline & $\begin{array}{l}\text { Multi-directional straightened } \\
\text { arrangement of collagen }\end{array}$ & $\begin{array}{l}\text { Unidirectional straightened } \\
\text { arrangement of collagen }\end{array}$ & $\begin{array}{l}\text { Unidirectional wavy } \\
\text { arrangement of collagen }\end{array}$ \\
\hline & - & Fibroblasts & Fibroblasts \\
\hline & Type II collagen & - & - \\
\hline \multirow{8}{*}{ Lateral part } & Type I collagen & Dense type I collagen & Semi-dense type I collagen \\
\hline & Multi-directional straightened & Unidirectional straightened & Unidirectional wavy \\
\hline & - & Fibroblasts & Fibroblasts \\
\hline & Hyaluronan & - & Hyaluronan \\
\hline & Ruffini and Pacinian corpuscles & - & Ruffini and Pacinian corpuscles \\
\hline & Blood vessels & - & Blood vessels \\
\hline & Nerves & - & - \\
\hline & Type II collagen & - & - \\
\hline \multirow{11}{*}{ Medial part } & Loose connective tissue & Loose connective tissue & Loose connective tissue \\
\hline & Type I collagen & Few type I collagen & Few type I collagen \\
\hline & Type III collagen & Type III collagen & Type III collagen \\
\hline & $\begin{array}{l}\text { Multi-directional arrangement of } \\
\text { Elastic fibres }\end{array}$ & $\begin{array}{l}\text { Multi-directional arrangement of } \\
\text { Elastic fibres }\end{array}$ & $\begin{array}{l}\text { Multi-directional arrangement } \\
\text { Elastic fibres }\end{array}$ \\
\hline & - & Reticular fibres & Reticular fibres \\
\hline & - & Fibroblasts & Fibroblasts \\
\hline & Blood vessels & - & Blood vessels \\
\hline & Nerves & - & Nerves \\
\hline & Ruffini and Pacinian corpuscles & - & - \\
\hline & Type II collagen & - & - \\
\hline & Hyaluronan & - & - \\
\hline
\end{tabular}

central and lateral parts resembled an aponeurosis, therefore, the findings suggest that these two parts may be considered as the PA. Histological analysis also revealed that the medial part resembled fascia, hence, the findings also suggest that this part should be considered as the PF. In recent years, there has been an increase in studies investigating the role of fascia and aponeurosis in musculoskeletal disorders, such as myofascial pain (Stecco et al.). Thus understanding the macro- and micro-properties of fascia and aponeurosis may aid in treating these disorders. Understanding the anatomy of the PA is also important to orthopedic surgeons for diagnoses and treatment of pathologies such as plantar fasciitis, as the central part of the PA is known to be directly involved in the pathology.

KALICHARAN, A.; PILLAY, P.; RENNIE, C.O.; DE GAMA, B. Z. \& SATYAPAL, K. S. La Aponeurosis Plantar en Fetos y Adultos: ¿Aponeurosis o Fascia? Int. J. Morphol., 35(2):684-690, 2017.

RESUMEN: La aponeurosis plantar (AP), que es una capa engrosada de fascia profunda localizada en la superficie plantar del pie, está compuesta de tres partes. Hay diferentes opiniones sobre su nomenclatura, ya que varios autores utilizan los términos AP y fascia plantar (FP) de forma intercambiable. Además, las distintas clasificaciones de sus partes han dado lugar a confusión. Con el fin de evaluar la naturaleza de la AP, este estudio documentó su morfología. Además, se realizó un análisis histológico para examinar si la estructura es una aponeurosis o fascia. Este estudio consistió en un análisis morfológico de las tres partes de la AP de 50 pies de fetos y 50 pies de cadáveres adultos, por micro y macrodisección, respectivamente (total $\mathrm{n}=100$ ). Además, se realizó un análisis histológico en cinco fetos $(\mathrm{n}=10)$ y cinco adultos $(\mathrm{n}=10)$ (total $\mathrm{n}=20)$. En cada pie, el análisis histológico se realizó sobre las tres partes de la aponeurosis plantar, es decir, la central, lateral y medial en su origen calcáneo (total $n=60$ ). Fetos: i) Morfología: En el 66 \% (33/50) de los especímenes, se observó el patrón anatómico estándar, es decir, tres partes (central, lateral y medial) que se originaron a partir de los procesos medial y lateral de la tuberosidad calcánea y se insertaban en los metatarsianos. En $18 \%$ (9/50) de los especímenes, se observó una estructura de dos partes. Los orígenes variables de la parte mediana se visualizaron en el $16 \%(8 / 50)$ de los especímenes. Para documentar estas variaciones, la parte central de la AP se dividió en tres segmentos (superior, medio, inferior): en el $63 \%$ (5/8) de los casos, la parte mediana surgió del segmento medio; en el 37 \% (3/8) de los casos, 
los casos la parte medial surgió de los segmentos medio y superior. ii) Análisis histológico: a) La parte central contenía fibras de colágeno tipo I semi-densas dispuestas longitudinalmente con fibroblastos; b) La parte lateral mostró fibras de colágeno tipo I semi-densas con fibroblastos, ácido hialurónico, corpúsculo sensorial fusiform (corpúsculo de Ruffini) y corpúsculo lamellosum (corpúsculo de Pacini); c) La parte medial comprende tejido conjuntivo suelto con fibras elásticas y reticulares. Adultos: i) Morfología: En el $100 \%$ de los especímenes se observó el patrón anatómico estándar. ii) Análisis histológico: a) En la parte central, se observaron fibras de colágeno de tipo I con disposición longitudinal de fibroblastos; b) La parte lateral contenía fibras de colágeno de tipo I dispuestas longitudinalmente con fibroblastos; c) La parte medial estaba compuesta de tejido conectivo suelto, fibras de colágenos tipo I y tipo III, fibras elásticas y reticulares. En el presente estudio, la morfología de la AP en fetos y adultos se ajustó a la descripción anatómica estándar con variaciones en el origen de la parte medial observada en fetos. Además, los especímenes fetales mostraron una estructura de dos partes de la AP cuando la parte medial estaba ausente. Microscópicamente, los hallazgos sugieren que sólo las partes central y lateral pueden considerarse como AP, mientras que la parte medial puede denominarse FP.

PALABRAS CLAVE: Aponeurosis; Fascia Histología; Morfología; Embriología.

\section{REFERENCES}

Abrahams, P. H.; Spratt, J. D.; Loukas, M. \& Van Schoor, A. N. McMinn and Abrahams' Clinical Atlas of Human Anatomy. $7^{\text {th }}$ ed. Philadelphia, Elsevier/ Mosby, 2013. pp.350.

Chaurasia, B. D. B. D. Chaurasia's Human Anatomy. Regional \& Applied. Dissection \& Clinical. New Dheli, CBS Publishers \& Distributors Pvt. Ltd., 2010.Chen, D. W.; Li, B.; Aubeeluck, A.; Yang, Y. F.; Huang, Y. G.; Zhou, J. Q. \& Yu, G. R. Anatomy and biomechanical properties of the plantar aponeurosis: a cadaveric study. Plos one, 9(1):e84347, 2014.

Moraes do Carmo, C. C.; Fonseca de Almeida Melão, L. I.; Valle de Lemos Weber, M. F.; Trudell, D. \& Resnick, D. Anatomical features of plantar aponeurosis: cadaveric study using ultrasonography and magnetic resonance imaging. Skeletal Radiol., 37(10):929-35, 2008.

Drake, R. L.; Vogl, W. \& Mitchell, A. W. M. Gray's Anatomy for Students. $3^{\text {rd }}$ ed. Churchill Livingstone/Elsevier, 2015. pp.649.

Federative Committee on Anatomical Terminology (FCAT). Terminologia Anatomica: International Anatomical Terminology. New York, Thieme Medical Publishers, 1998.

Hiramoto, Y. Shape of the fibular part of the plantar aponeurosis in Japanese. Okajimas Folia Anat. Jpn., 60(5):329-37, 1983.

Hoffman, D. F.; Grothe, H. L. \& Bianchi, S. Sonographic evaluation of hindfoot disorders. J. Ultrasound, 17(2):141-50, 2014.

Kalniev, M. A.; Krastev, D.; Krastev, N.; Vidinov, K.; Veltchev, L. \& Mileva, M. Abnormal attachments between a plantar aponeurosis and calcaneus. Clujul Med., 86(3):200-2, 2013.

Kaya, B. K. Plantar fasciitis in athletes. J. Sport Rehab., 5:305-20, 1996.

Hall, B. K. Evolutionary Developmental Biology. $2^{\text {nd }}$ ed. Dordrecht, Kluwer Academic Publishers, 1998.

Kelikian, A. S. Sarrafian's Anatomy of the Foot and Ankle. Descriptive, Topographic, Functional. $3^{\text {rd }}$ ed. Philadelphia, Wolters Kluwer health Lippincott Williams \& Wilkins, 2011.

Loth, E. Die Aponeurosis plantaris in der Primatenreihe mit Spezieller Berücksichtigung des Menschen: Eine Vergleichend-Morphologische und Anthropologische Untersuchung. Leipzig, Wilhelm Engelmann, 1908.
Loth, E. Etude anthropologique sur laponévrose plantaire. Bull. Mem. Soc. Anthro. Paris, 4:601, 1913.

McNally, E. G. \& Shetty, S. Plantar fascia: imaging diagnosis and guided treatment. Semin. Muskuloskelet. Radiol., 14(3):334-43, 2010.

Mescher, A. L. Junqueira's Basic Histology: Text and Atlas. 13th ed. New York, McGraw-Hill Medical, 2013

Moore, K. L.; Dalley, A. F. \& Agur, A. M. R. Clinically Oriented Anatomy. $7^{\text {th }}$ ed. Philadelphia, Wolters Kluwer, 2014.

Moore, K. L.; Persaud, T. V. N. \& Torchia, M. G. The Developing Human. Clinically Oriented Embryology. 10 ${ }^{\text {th }}$ ed. Philadelphia, Elsevier, 2016.

Netter, F. H. Netter's Atlas of Human Anatomy. 6th ed. London, Elsevier Health Sciences, 2014.

Pandey, V. D.; Singh, V.; Nigam, G. L.; Usmani, Y. \& Yadav, Y. Fetal foot length for assessment of gestational age: A comprehensive study in North India. Sch. J. Appl. Med. Sci., 3(1C):139-44, 2015.

Pavan, P. G.; Pachera, P.; Stecco, C. \& Natali, A. N. Constitutive modeling of time-dependent response of human plantar aponeurosis. Comput. Math. Methods Med., 2014:530242, 2014.

Ross, M. H. \& Pawlina, W. Histology. A Text and Atlas. With Correlated Cell and Molecular Biology. 7th ed. Philadelphia, Wolters Kluwer, 2015.

Sakalauskaite, R. \& Satkunskiene, D. The foot arch and viscoelastic properties of plantar fascia and Achilles tendon. J. Vibroengineering, 14(4):1751-9, 2012.

Sinnatamby, C. S. Last's Anatomy. Regional and Applied. $12^{\text {th }}$ ed. Edinburgh, Churchill Livingstone, 2011. pp.151.

Snell, R. S. Clinical Anatomy by Regions. $9^{\text {th }}$ ed. Philadelphia, Lippincott Williams \& Wilkins, 2011.

Standring, S. (Ed.). Gray's Anatomy. The Anatomical Basis of Clinical Practice. $40^{\text {th }}$ ed. Edinburgh, Churchill Livingstone/Elsevier, 2008.

Standring, S. (Ed.). Gray's Anatomy. The Anatomical Basis of Clinical Practice. $41^{\text {th }}$ ed. Oxford, Elsevier, 2016.

Stecco, C.; Corradin, M.; Macchi, V.; Morra, A.; Porzionato, A.; Biz, C. \& De Caro, R. Plantar fascia anatomy and its relationship with Achilles tendon and paratenon. J. Anat., 223(6):665-76, 2013.

Wearing, S. C.; Smeathers, J. E.; Urry, S. R.; Hennig, E. M. \& Hills, A. P. The pathomechanics of plantar fasciitis. Sports Med., 36(7):585-611, 2006.

Young, B.; Lowe, J. S.; Stevens, A. \& Health, J. W. Wheater's Functional Histology. A Text and Colour Atlas. $5^{\text {th }}$ ed. Edinburgh, Churchill Livingstone/Elsevier, 2011.

\author{
Corresponding author: \\ Prof. K.S. Satyapal \\ Clinical Anatomy \\ School of Laboratory Medicine and Medical Sciences \\ College of Health Sciences \\ University of KwaZulu-Natal \\ Westville Campus \\ Private Bag X54001 \\ Durban \\ 4000 \\ SOUTH AFRICA
}

E-mail: satyapalk@ukzn.ac.za

Received: 18-11-2016

Accepted: 17-02-2017 